\title{
ANALISIS KINERJA TENAGA PENDIDIK DAN KEPENDIDIKAN (DOSEN DAN KARYAWAN) PADA STIMI BANJARMASIN
}

\author{
"Mahfuzil Anwar" \\ Dosen Sekolah Tinggi Ilmu Manajemen Indonesia (STIMI) Banjarmasin
}

\begin{abstract}
This study aims to obtain empirical evidence on the performance of educators (lecturers), especially on the main task of implementing education and learning. In addition to educators of this research will also analyze the performance of education personnel (employees) in performing the task of serving students at STIMI Banjarmasin

The hypothesis is Hypotesis I, The performance of educators (lecturers) is good, and Hypothesis II, the performance of educational staff (employees) on STIMI Banjarmasin is good.

Through questionnaires submitted to respondents with indicators of learning with 5 items of questions, skills with 4 items of questions, assessment and workload with 2 items of questions, guidance and counseling with 2 items of questions, and learning resources with 2 items of questions, for educators (lecturers ) As many as 23 people. As for the education personnel (employees) as many as 8 people, with the indicator of responsibility with 3 items of questions, quality with 3 items of questions, quantity with 2 items of questions, and discipline with 2 question items.

The results showed that for the performance of educators (lecturers) showed good results, while the performance of educational personnel (employees) showed good results.
\end{abstract}

Keyword : lecturer performance, employees performance

\begin{abstract}
ABSTRAK
Penelitian ini bertujuan untuk mendapatkan bukti empiris tentang Kinerja tenaga pendidik (dosen) terutama pada tugas utama yaitu melaksanakan pendidikan dan poengajaran. Disamping tenaga pendidik penelitian ini juga akan menganalisis kinerja tenaga kependidikan (karyawan) dalam melaksanakan tugas melayani mahasiswa pada STIMI Banjarmasin

Hipotesis yang dikekamukan adalah Hipotesis I, Kinerja tenaga pendidik (dosen) sudah baik, dan Hipotesis II, kinerja tenaga kependidikan (karyawan) pada STIMI Banjarmasin sudah baik.

Melalui kuesioner yang diajukan kepada responden dengan indikator Pembelajaran dengan 5 item pertanyaan, keterampilan dengan 4 item pertanyaan, penilaian dan beban kerja dengan 2 item pertanyaan, bimbingan dan konseling dengan 2 item pertanyaan, dan sumber pembelajaran dengan 2 item pertanyaan, untuk tenaga pendidik (dosen) sebanyak 23 orang. Sedangkan untuk tenaga kependidikan (karyawan) sebanyak 8 orang, dengan indikator tanggung jawab dengan 3 item pertanyaan, kualitas dengan 3 item pertanyaan, kuantitas dengan 2 item pertanyaan, dan disiplin dengan 2 item pertanyaan.

Hasil penelitian menunjukkan bahwa untuk kinerja tenaga pendidik (dosen) menunjukkan hasil yang baik, sedangkan kinerja tenaga kependidikan (karyawan) menunjukkan hasil cukup baik.
\end{abstract}

Kata Kunci : Kinerja Dosen, Kinerja Karyawan 


\section{PENDAHULUAN}

$\begin{aligned} & \text { Salah satu kegiatan yang dapat } \\ & \text { oleh }\end{aligned}$
dilakukan suatu
badan/ogranisasi/lembaga untuk dapat
meningkatkan kinerja dosen maupun
karyawan melalui beberapa indikator yang
akan dibahas dalam penelitian ini.

Tercapainya tujuan organisasi atau perusahaan hanya dimungkinkan karena upaya pelaku yang terdapat pada sebuah organisasi/lembaga tersebut. Pada dasarnya terdapat hubungan yang erat antara kinerja seseorang dengan kinerja organisasi, dalam hal ini adalah kinerja tenaga pendidik (dosen) dan tenaga kependidikan (karyawan). Manusia selalu berperan aktif dan dominan dalam setiap kegiatan organisasi, karena manusia menjadi perencana, pelaku dan penentu terwujudnya tujuan organisasi. Tujuan ini tidak mungkin terwujud tanpa adanya peranan aktif dari manusia.

Individu-individu yang terlibat dalam organisasi memiliki banyak aspek yang dapat memberi konstribusi bagi pencapaian tujuan organisasi yang meliputi pengetahuan, pengalaman, keterampilan, kepribadian, perasaan dan kemauan yang berbeda-beda dan aspek-aspek tersebut menciptakan suatu perilaku, dimana perilaku manusia tersebut dipelajari didalam lingkungan kerja dan didalam melaksanakan tugas pekerjaannya.

Manusia juga dipelajari dalam interaksinya dengan pekerjaannya, dengan lingkungan kerja fisiknya, dan dengan lingkungan sosial pekerjaannya dimana hal tersebut merupakan hubungan timbal balik dan saling mempengaruhi. Namun demikian, tenaga pendidik (dosen) dan tenaga kependidikan (karyawan), tidak selalu berhasil dalam memerankan perannya tanpa menimbulkan masalah. Fenomena ini bisa terjadi karena masalah yang dihadapi dapat ditimbulkan oleh situasi dan kondisi dimana mereka berada. Begitu pula kekuatan, kelemahan maupun hal lain yang ada pada diri tenaga pendidik maupun kependidikan merupakan potensi yang nantinya akan berpengaruh pada kinerjanya.

Indikator untuk menilai kinerja tenaga pendidik (dosen) khususnya pada bidang pendidikan dan pengajaran, antara lain dapat dilihat pada 1) Pembelajaran 2) Keterampilan, 3) Penilaian dan beban kerja, 4) Bimbingn dan konseling serta 5) Sumber Pembelajaran.

Sedangkan indikator untuk menilai kinerja tenaga kependidikan (karyawan) dalam hal pelayanan dapat dilihat dari beberapa hal yaitu : 1) Tanggung jawab, 2) Kualitas, 3) Kuantitas, dan 4) Disiplin.)

Dari indikator-indikator diatas tersebut akan dianalisis bagaimana kinerja tenaga pendidik (dosen) dan tenaga kependidikan (karyawan) seperti tenaga Administrasi Akademik, tenaga perpustakaan serta tenaga administrasi kepegawaian dan umum.

Perumusan masalah yang dikemukakan dalam penelitian ini adalah : a) Bagaimana kinerja tenaga pendidik (dosen) pada STIMI Banjarmasin selama ini ?. b) Bagaimana kinerja tenaga kependidikan (karyawan) pada STIMI Banjarmasin selama ini?.

Tujuan Penelitian : a) Untuk mengetahui dan menganalisis kinerja tenaga pendidik (dosen) STIMI Banjarmasin khususnya dalam bidang pendidikan dan pengajaran. b) Untuk mengetahui dan menganalisis kinerja tenaga kependidikan (karyawan) STIMI Banjarmasin dalam hal pendidikan dan pengajaran.

Manfaat Penelitian : a) Secara teoritis memberikan konstribusi bagi ilmu pengetetahuan dalam bidang sumber daya manusia berupa tambahan referensi yang memungkinkan peneliti lain dapat melakukan penelitian terhadap masalah kinerja tenaga pendidik (dosen) dan tenaga kependidikan (karyawan) pada STIMI Banjarmasin. b) Memberikan informasi dan masukan bagi lembaga dalam rangka pelayanan terhadap mahasiswa khususnya pada tenaga kependidikan (karyawan) STIMI Banjarmasin. 


\section{TINJAUAN PUSTAKA}

\section{Landasan Teori}

Tantangan yang dihadapi pada masa sekarang ini dalam mengelola perguruan tinggi (PT) paling tidak mencakup tiga hal, pertama dengan adanya perubahan paradigma baru yang dipicu dengan perkembangan teknologi yang sedemikian cepat, kedua, dalam penyelenggaraan perguruan tinggi dengan munculnya BHMN dan BHP, dan ketiga, persaingan yang sedemikian ketat baik dengan perguruan tinggi yang ada di dalam maupun luar negeri.

Untuk mengantisipasi perubahan yang terjadi dan juga dalam rangka untuk menghadapi tantangan tersebut diperlukan adanya sumberdaya manusia yang unggul, setiap perguruan tinggi dituntut untuk dapat mengelola sumberdaya manusia dan mengevaluasi kinerjanya, baik tenaga pendidik (dosen) maupun tenaga kependidikan (karyawan). Agar sumberdaya manusia yang dikelola dapat diketahui efektifitasnya maka perlu adanya pengukuran kinerja yang komprehensif dan terarah. Pengukuran kinerja yang tepat bagi dosen dan karyawan yang merupakan salah satu civitas akademika menjadi sangat urgen untuk dilakukan.

Namun pada masa sekarang ini banyak perguruan tinggi yang belum mempunyai sistem penilaian yang komprehensif bagi dosen dan karyawan sehingga banyak para pimpinan perguruan tinggi merasa bingung apabila menghadapi dosen maupun karyawan yang kinerjanya kurang optimal.

Untuk itu sangat diperlukan adanya pelatihan/workshop dalam rangka penyusunan penilaian dosen dan karyawan pada perguruan tinggi, dengan tujuan :

1. Memahami konsep penilaian kinerja

2. Mengerti indikator kinerja dosen dan pegawai/karyawan

3. Memahami aplikasi penilaian kinerja

4. Mengetahui pelaporan dan umpan balik dari penilaian kinerja

\section{Pengertian Kinerja}

Menurut Wibowo (2007), kinerja adalah tentang melakukan pekerjaan dan hasil yang dicapai dari pekerjaan tersebut. Kinerja adalah tentang apa yang dikerjakan dan bagaimana cara mengerjakannya. Anwar Prabu Mangkunegara (2007) mengemukakan Kinerja berasal dari kata Job Performance atau Actual Performance adalah hasil kerja secara kualitas dan kuantitas yang dicapai oleh seorang pegawai dalam melaksanakan tugasnya sesuai dengan tanggung jawab yang diberikan kepadanya.

Pada dasarnya, kinerja adalah apa yang dilakukan atau tidak dilakukan karyawan. Sedangkan kinerja karyawan adalah hasil kerja yang dicapai oleh seorang karyawan, atau organisasi dalam melaksanakan tugas dan pekerjaan sesuai tanggungjawab dan wewenang yang diberikan kepadanya mencakupi :

1. Kuantitas output

2. Kualitas output

3. Jangka waktu output

4. Kehadiran ditempat kerja

5. Sikap kooperatif

Kinerja karyawan (job performance) adalah hasil kerja yang dicapai oleh seorang karyawan atau organisasi dalam melaksanakan tugas dan pekerjaan sesuai tanggung jawab dan wewenang yang diberikan padanya. Bernandin dan Russell dalam Faustino Cardoso Gomes (1995) memberi batasan mengenai performansi sebagai "the record of outcomes produced on a specified job function or activity during, a specified time periode" (catatan outcome yang dihasilkan dari fungsi suatu pekerjaan tertentu atau kegiatan selama suatu periode waktu tertentu). Sedangkan penilaian performansi adalah " $a$ way of measuring the contributions of individuals to their organization" (suatu cara mengukur kontribusi-konstribusi dari individu-individu anggota organisasi kepada organisasinya).

Sedarmayanti (2009), Kinerja terjemahan dari Performance, berarti : 
1. Perbuatan, pelaksanaan pekerjaan, prestasi kerja, pelaksanaan pekerjaan yang berdaya guna ;

2. Pencapaian/prestasi seseorang berkenaan dengan tugas yang diberikan kepadanya :

3. Hasil kerja seorang pekerja, sebuah proses manajemen atau suatu organisasi secara keseluruhan, dimana hasil kerja tersebut harus dapat ditunjukkan buktinya secara konkrit dan dapat diukur (dibandingkan dengan standar yang telah ditentukan);

4. Kinerja didefinisikan sebagai catatan mengenai out come yang dihasilkan dari suatu aktivitas tertentu, selama kurun waktu tertentu pula;

5. Hasil kerja yang dapat dicapai oleh seseorang atau sekelompok orang dalam suatu organisasi sesuai dengan wewenang dan tanggungjawab masingmasing, dalam rangka upaya mencapai tujuan organisasi bersangkutan secara legal, tidak melanggar hukum dan sesuai dengan moral maupun etika.

\section{Pengertian Penilaian kinerja}

1. Penilaian kinerja adalah proses yang dilakukan organisasi untuk mengevaluasi hasil kerja para karyawannya. (Werther \& Davis 1996)

2. Penilaian kinerja adalah sistem formal untuk meninjau dan mengevaluasi kinerja para individu atau tim dalam menjalankan tugasnya. (Mondy 2008)

3. Penilaian kinerja melibatkan evaluasi kinerja yang didasarkan pada penilaian dan pendapat dari para bawahan, rekan kerja, atasan, manajer lainnya, dan bahkan karyawan itu sendiri. (Schuler \& Jackson 2006)
4. Penilaian kinerja adalah proses formal untuk mengevaluasi kinerja dan memberi umpan balik. (Schermerhorn 1996)

5. Penilaian kinerja berarti mengevaluasi kinerja karyawan saat ini dan/atau di masa lalu relatif terhadap standar prestasinya. (Dessler 2006)

6. Penilaian kinerja adalah proses formal untuk mengevaluasi kinerja dan memberi umpan balik. (Schermerhorn 1996)

\section{Tujuan Evaluasi Kinerja Dosen}

Dalam perkembangan yang kompetitif dan mengglobal, setiap lembaga, termasuk lembaga pendidikan membutuhkan personil, terutama tenaga pendidik (dosen) yang berprestasi tinggi. Pada saat yang sama setiap personil memerlukan umpan balik atas kinerja mereka sebagai pedoman bagi tindakantindakan mereka pada masa yang akan datang oleh karena itu penilaian yang dilakukan seharusnya menggambarkan kinerja personil. Hasil penilaian kinerja dapat menunjukkan apakah SDM yang ada telah memenuhi tuntutan yang dikehendaki lembaga, baik dilihat dari kualitas maupun kuantitas. Informasi dalam penilaian kinerja personil merupakan refleksi dari berkembang tidaknya lembaga.

Penilaian kinerja mengacu pada suatu sistem formal dan terstruktur yang digunakan untuk mengukur, menilai dan mempengaruhi sifat-sifat yang berkaitan dengan pekerjaan, perilaku dan hasil. Dengan dimikian, penilaian prestasi adalah merupakan hasil kerja personil dalam lingkup tanggung jawabnya.

Kinerja dosen pada suatu perguruan tinggi merupakan perilaku nyata yang ditampilkan setiap dosen sebagai prestasi kerja yang dihasilkan oleh dosen tersebut sesuai dengan peranannya. Untuk dapat menentukan kualitas kinerja dosen perlu adanya kriteria yang jelas. Mitchell (1978) menyatakan bahwa kinerja meliputi beberapa aspek, yaitu: aspek kualitas 
pekerjaan, ketepatan waktu, prakarsa, kemampuan dan komunikasi.

Kinerja dosen merupakan suatu hal yang sangat penting dalam upaya lembaga perguruan tinggi untuk mencapai tujuanya. Di dalam dunia yang kompetitip dan mengglobal ini, setiap perguruan tinggi, memerlukan kinerja dosen yang tinggi. Pada saat yang bersamaan, dosen sebagai ujung tombak suatu perguruan tinggi memerlukan umpan balik dari lembaga atas hasil kerja mereka sebagai panduan bagi perilaku mereka di masa yang akan datang. Umpan balik terhadap kinerja dosen dapat

dilakukan melalui evaluasi kinerja. Penilaian kinerja dosen merupakan suatu proses dimana lembaga melakukan evaluasi atau menilai kinerja dosen atau mengevaluasi hasil pekerjaan dosen. Penilaian yang dilakukan terhadap dosen dilaksanakan dengan berbasis pada pengawasan, artinya penilaian yang dilakukan terhadap dosen tidak saja ditujukan untuk menilai kinerja, juga sekaligus berfungsi untuk mengawasi dosen dalam melaksanakan tugas pokoknya, yaitu kegiatan pendidikan dan pengajaran, oleh karena itu kriteria yang dijadikan untuk mengevaluasi, sekaligus berfungsi sebagai alat untuk mengawasi kinerja dosen. Evaluasi kinerja dosen yang berbasis pengawasan ini bisa dilaksanakan oleh pimpinan jurusan, mahasiswa maupun tenaga yang ditetapkan oleh fakultas.

\section{Sasaran Evaluasi Kinerja Dosen}

Salah satu tugas dan tanggung jawab dosen, sebagaimana diamanatkan dalam Peraturan Pemerintah No.60 tahun 1999, adalah melaksanakan pendidikan dan pengajaran. Tugas ini, merupakan tugas utama seorang dosen yang harus dilaksanakan dengan sungguh-sungguh karena sebagai realisasi dari tugas utama suatu perguruan tinggi, yaitu melaksanakan kegiatan proses belajar mengajar dalam upaya mendidik mahasiswa.
Sebagai tenaga pendidik, dosen mengemban tugas dan tanggung jawab untuk mengembangkan potensi yang dimiliki mahasiswa, baik segi pengetahuan, keterampilan dan sikap yang sesuai dengan tujuan yang telah ditetapkan.

Sesuai dengan tugas utama dosen sebagai tenaga pendidik dalam melaksanakan pendidikan dan pengajaran, maka yang menjadi sasaran evaluasi kinerja dosen meliputi :

1. Persiapan atau perencanaan pembelajaran yang dilakukan dosen, seperti: penyusunan dan pengembangan SAP, Silabus, Handout Perkuliahan ;

2. Pelaksanaan pembelajaran, antara lain kemampuan dalam penyampaian materi pelajaran, penguasaan materi, penggunaan alat bantu pendidikan, manajemen kelas, pemberian tugastugas perkuliahan, penggunaan metoda pembelajaran ;

3. Evaluasi hasil belajar meliputi: antara lain penetapan alat atau jenis evaluasi yang digunakan, kesesuaian penggunaan jenis evaluasi dengan tujuan pembelajaran, relevansi antara soal dengan materi perkuliahan yang disampaikan mahasiswa.;

4. Kemampuan dosen dalam menjalin atau berinteraksi dengan mahasiswa, memotivasi, membantu mahasiswa yang mengalami masalah dalam belajar.

Aspek-aspek yang menjadi ukuran dalam mengevaluasi kinerja dosen tersebut, meliputi:

(a). Kualitas hasil kerja (quality of work),

(b). Kemampuan (capability),

(c). Prakarsa (initiative)

(d). Komunikasi (communication), dan

(e). Ketepatan waktu (promtness).

Dengan adanya penilaian kinerja terhadap dosen dapat diketahui secara tepat apa yang sedang dihadapi dan target apa yang harus dicapai. Melalui penilaian kinerja dosen dapat disusun rencana, strategi dan menentukan langkah-langkah 
yang perlu diambil sehubungan dengan pencapaian tujuan karier yang diinginkan.

Bagi pihak manajemen, kinerja tenaga pendidik (dosen) sangat membantu dalam mengambil keputusan seperti promosi dan pengembangan karier, mutasi, PHK, penyesuaian kompensasi, kebutuhan pelatihan (John M. Ivancevich, Andrew D. Szilagyi, Jr. \& Marc J. Wallace, Jr., 1987) dan mempertahankan status akreditasi perguruan tinggi yang telah diperoleh.

Faktor-faktor Yang Mempengaruhi Kinerja Menurut Mangkunegara (2001) faktor-faktor yang mempengaruhi kinerja seseorang ialah :

(1) Faktor kemampuan, secara umum kemampuan ini terbagi menjadi 2 yaitu kemampuan potensi (IQ) dan kemampuan reality (knowledge dan skill). Seorang dosen seharusnya memiliki kedua kemampuan tersebut agar dapat menyelesaikan jenjang pendidikan formal minimal S2 dan memiliki kemampuan mengajar dalam mata kuliah yang diampunya.

(2) Faktor motivasi, motivasi terbentuk dari sikap dosen dalam menghadapi situasi kerja. Motivasi bagi dosen sangat penting untuk mencapai visi dan misi institusi pendidikan. Menjadi dosen hendaknya merupakan motivasi yang terbentuk dari awal (by plan), bukan karena keterpaksaan atau kebetulan (by accident).

\section{Menyusun Penilaian Kinerja}

Untuk menyusun pedoman penilaian kinerja, sebaiknya dibentuk suatu tim yang diberi penugasan secara khusus. Anggota tim dapat terdiri dari manajemen perguruan tinggi yang menangani sumberdaya manusia, misalnya Wakil Ketua I, II dan III, unsur dosen dan senat. Dengan melibatkan tim yang terdiri dari berbagai unsur hasilnya akan lebih objektif dan penghargaan dosen terhadap pedoman penilaian juga lebih besar.
Hal-hal yang harus diperhatikan dalam menyusun pedoman kinerja ialah sistem penilaian harus mempunyai hubungan dengan pekerjaan yang dinilai, praktis, mempunyai standar dan menggunakan berbagai ukuran yang dapat diandalkan (Handoko, 1994). Penilaian kinerja perlu dilaksanakan secara formal dengan menentukan periode penilaian dan waktu penilaian. Lazimnya periode penilaian adalah satu tahun, sedangkan waktu penilaian dapat dilakukan satu kali setahun atau satu semester sekali. Periode dan waktu penilaian sebaiknya diketahui oleh dosen dan penilai. Setelah penilaian dilakukan, dosen hendaknya mengetahui hasilnya. Hasil penilaian dapat diberikan secara tertulis kepada dosen dan karyawan serta diberi kesempatan untuk melakukan klarifikasi atau complain apabila terdapat kekeliruan dalam penilaian.

\section{Manfaat penilaian Kinerja}

1. Perbaikan kinerja

2. Penyesuaian kompensasi

3. Penempatan karyawan

4. Kebutuhan pelatihan dan pengembangan

5. Perencanaan dan pengembangan karir

6. Mendeteksi kelemahan proses staffing

7. Mendeteksi ketidaktepatan informasi

8. Mendeteksi kesalahan desain jabatan

9. Menjamin kesempatan kerja yang setara

10. Mendeteksi faktor eksternal yang mempengaruhi kinerja

11. Memberikan umpan balik bagi departemen SDM

\section{Kerangka Konseptual}

Berdasarkan landasan teori yang dikemukakan, maka kerangka konseptual dalam penelitian ini dapat dikemukakan seperti tampak pada bagan 1 berikut : 


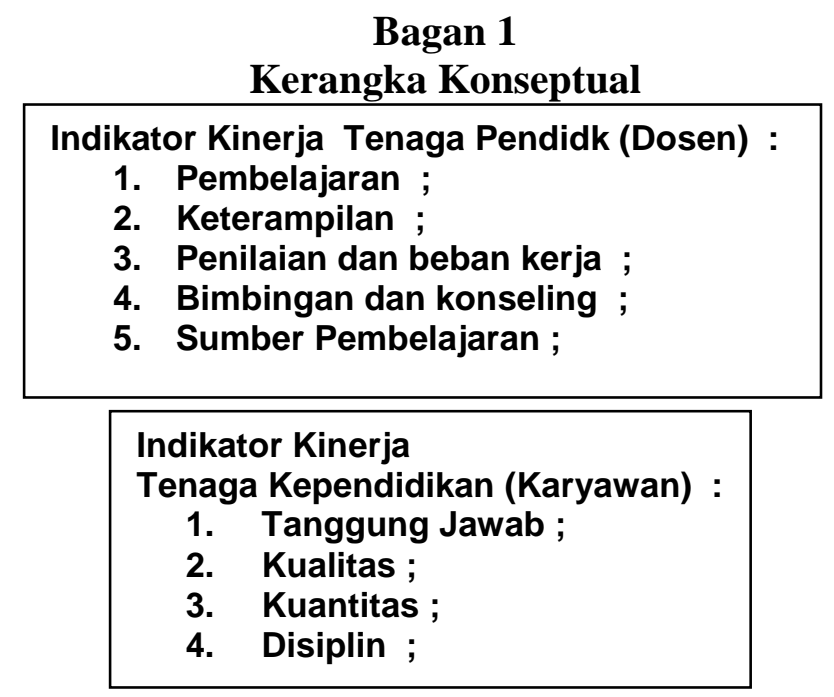

\section{Hipotesis}

1. Kinerja tenaga pendidik (dosen) pada STIMI Banjarmasin sudah baik

2. Kinerja tenaga kependidikan (karyawan) pada STIMI Banjarmasin sudah baik.

\section{METODE PENELITIAN}

Metode Penelitian, sesuai dengan tujuan penelitian yang telah dirumuskan, maka penelitian ini menggunakan pola statistik deskriptif yaitu penelitian yang bermaksud menganalisis data dengan cara mendeskripsikan atau menggambarkan data yang terkumpul sebagaimana adanya tanpa bermaksud untuk membuat kesimpulan yang berlaku umum atau generalisasi. Pola statistik deskriptif ini tidak dilakukan uji signifikani dan tidak ada taraf kesalahan dan penyajian data melalui table, perhitungan median, mean dan lain-lain.

Sanusi (2014) Populasi diartikan seluruh kumpulan elemen yang menunjukkan ciri tertentu yang dapat digunakan untuk membuat kesimpulan. Jadi kumpulan elemen itu menunjukkan jumlah, sedangkan ciri-ciri tertentu menunjukkan karakteristik dari kumpulan itu. Keseluruhan kumpulan elemen disebut populasi, namun biasanya dilakukan seleksi terhadap bagian elemen dari populasi dengan harapan dapat merefleksikan seluruh karakteristik yang ada. Elemen adalah subjek dimana pengukuran itu dilakukan. Sanusi (2014) bagian dari elemen-elemen populasi yang dipilih disebut sampel. (Sugiyono, 2002). Populasi adalah keseluruhan subjek penelitian. Sedangkan sampel adalah sebagian atau wakil populasi yang diteliti (Suharsimi Arikunto, 2006).

Dari definisi tersebut, sampel yang diambil adalah seluruh populasi, dalam penelitian ini yaitu tenaga pendidik (dosen) yang berstatus Dosen PNS Dpk, Dosen Yayasan dan Dosen Luar Biasa yang berjumlah 23 orang serta tenaga kependidikan (karyawan) yang berjumlah 8 orang, dengan demikian dalam penelitian ini metode sensus yang digunakan karena seluruh populasi dalam penelitian ini dijadikan sampel.

Teknik analisa data adalah mendeskripsikan teknik analisis apa yang akan digunakan dalam penelitian. Pada penelitian ini penulis menggunakan teknik analisis data statistik deskriptif yaitu penyajian data dengan tabel, perhitungan mean dan prosentase. Pada penelitian ini tidak dilakukan uji signifikan dan tidak ada taraf kesalahan karena peneliti tidak bermakud membuat generalisasi.

Pembuktian hipotesis dilakukan dengan membuat tabel frekuensi serta validitas dan realibility data. Kinerja tenaga pendidik (dosen) pada STIMI Banjarmasin sudah baik. Kinerja tenaga kependidikan (karyawan) pada STIMI Banjarmasin sudah baik. 


\section{A. Hasil Penelitian}

\section{HASIL PENELITIAN DAN PEMBAHASAN}

\section{Karakteristik Responden Tenaga Pendidik ( Dosen)}

Karakteristik responden yang terdiri dari umur, jenis kelamin, status dosen, masa kerja, tingkat pendidikan dan pangkat/golongan dapat disajikan seperti pada tabel 4.1 berikut :

TABEL 4.1

Karkteristik Demografi Responden Tenaga Pendidik (Dosen)

\begin{tabular}{|c|c|c|}
\hline Karaktersitik & Frekuensi (orang) & Prosentase $(\%)$ \\
\hline \multicolumn{3}{|l|}{ Umur } \\
\hline $26-30$ tahun & 2 & 8,7 \\
\hline $31--35$ tahun & 2 & 8,7 \\
\hline $36-40$ tahun & 5 & 21,7 \\
\hline $41-45$ tahun & 4 & 17,4 \\
\hline $46-50$ tahun & 1 & 4,3 \\
\hline$>50$ tahun & 9 & 39,1 \\
\hline Jumlah & 23 & 100 \\
\hline \multicolumn{3}{|l|}{ JenisKelamin : } \\
\hline Laki-Laki & 13 & 56,5 \\
\hline Perempuan & 10 & 43,5 \\
\hline Jumlah & 23 & 100 \\
\hline \multicolumn{3}{|l|}{ Status Dosen : } \\
\hline PNS Dpk & 5 & 21,7 \\
\hline Dosen Tetap Yayasan & 11 & 47,8 \\
\hline Dosen Luar Biasa & 7 & 30,4 \\
\hline Jumlah & 23 & 100 \\
\hline Karaktersitik & Frekuensi (orang) & Prosentase $(\%)$ \\
\hline \multicolumn{3}{|l|}{ Masa Kerja : } \\
\hline $1-5$ tahun & 3 & 13,0 \\
\hline $6-10$ tahun & 4 & 17,4 \\
\hline $11-15$ tahun & 3 & 13,0 \\
\hline $16-20$ tahun & 2 & 8,7 \\
\hline $21-25$ tahun & 5 & 21,7 \\
\hline$>25$ tahun & 6 & 26,1 \\
\hline Jumlah & 23 & 100 \\
\hline \multicolumn{3}{|l|}{ Tingkat Pendidikan : } \\
\hline S3 & 3 & 13,0 \\
\hline $\mathrm{S} 2$ & 19 & 82,6 \\
\hline S1 & 1 & 4,3 \\
\hline Jumlah & 23 & 100 \\
\hline \multicolumn{3}{|l|}{ Pangkat/Golongan : } \\
\hline $\mathrm{IV} / \mathrm{c}$ & 0 & 0,0 \\
\hline $\mathrm{IV} / \mathrm{b}$ & 2 & 8,7 \\
\hline $\mathrm{IV} / \mathrm{a}$ & 10 & 43,5 \\
\hline $\mathrm{III} / \mathrm{d}$ & 2 & 8,7 \\
\hline $\mathrm{III} / \mathrm{c}$ & 3 & 13,0 \\
\hline $\mathrm{III} / \mathrm{b}$ & 4 & 17,4 \\
\hline III/a & 2 & 8,7 \\
\hline Jumlah & 23 & 100 \\
\hline
\end{tabular}

Sumber; Data perimer diolah kembali, 2017 
Dari tabel 4.1, terlihat bahwa karakteristik responden dengan umur diatas 50 tahun $(39,1 \%)$, jenis kelamin laki-laki $(56,5 \%)$, status dosen lebih besar dosen dengan status dosen yayasan $(47,8 \%)$, masa kerja diatas 25 tahun $(26,1 \%)$, tingkat pendidikan S2 $(82,6 \%)$ dan pangkat/golongan terbesar IV/a (43,5\%), menunjukkan bahwa mayoritas tenaga pendidik (dosen) telah mempunyai masa kerja yang lama dan pangkat/golongan yang

TABEL 4.2

Karkteristik Demografi Responden Tenaga Kependidikan (Karyawan)

\begin{tabular}{|c|c|c|}
\hline Karaktersitik & Frekuensi (orang) & Prosentase $(\%)$ \\
\hline \multicolumn{3}{|l|}{ Umur } \\
\hline $27-30$ tahun & 1 & 12,5 \\
\hline $31--35$ tahun & 1 & 12,5 \\
\hline $36-40$ tahun & 1 & 12,5 \\
\hline $41-45$ tahun & 1 & 12,5 \\
\hline $46-50$ tahun & 2 & 25,0 \\
\hline$>50$ tahun & 2 & 25,0 \\
\hline Jumlah & 8 & 100 \\
\hline \multicolumn{3}{|l|}{ JenisKelamin : } \\
\hline Laki-Laki & 5 & 62,5 \\
\hline Perempuan & 3 & 37,5 \\
\hline Jumlah & 8 & 100 \\
\hline \multicolumn{3}{|l|}{ Status Perkawinan: } \\
\hline Kawin & 6 & 75,0 \\
\hline TidakKawin & 2 & 25,0 \\
\hline Jumlah & 8 & 100 \\
\hline Karaktersitik & Frekuensi (orang) & Prosentase $(\%)$ \\
\hline \multicolumn{3}{|l|}{ Masa Kerja : } \\
\hline $1-5$ tahun & 1 & 12,5 \\
\hline $6-10$ tahun & 1 & 12,5 \\
\hline $11-15$ tahun & 1 & 12,5 \\
\hline $16-20$ tahun & 1 & 12,5 \\
\hline $21-25$ tahun & 1 & 12,5 \\
\hline$>25$ tahun & 3 & 37,5 \\
\hline Jumlah & 8 & 100 \\
\hline \multicolumn{3}{|l|}{ Tingkat Pendidikan } \\
\hline $\mathrm{S} 2$ & 0 & 0,0 \\
\hline $\mathrm{S} 1$ & 2 & 25,0 \\
\hline D3 & 2 & 25,0 \\
\hline SLTA & 4 & 50,0 \\
\hline Jumlah & 8 & 100 \\
\hline \multicolumn{3}{|l|}{ Pangkat/Golongan : } \\
\hline $\mathrm{III} / \mathrm{a}$ & 2 & 25,0 \\
\hline $\mathrm{II} / \mathrm{d}$ & 2 & 25,0 \\
\hline $\mathrm{II} / \mathrm{c}$ & 1 & 12,5 \\
\hline $\mathrm{II} / \mathrm{b}$ & 2 & 25,0 \\
\hline $\mathrm{II} / \mathrm{a}$ & 1 & 12,5 \\
\hline Jumlah & 8 & 100 \\
\hline
\end{tabular}

Sumber ; Data primer diolah kembali, 2017 telah berada pada tingkat yang cukup tinggi.

\section{Karakteristik Responden Tenaga Kependidikan ( Karyawan)}

Karakteristik responden tenaga kependidikan (karyawan) yang terdiri dari umur, jenis kelamin, status pwrkawinan, masa kerja, tingkat pendidikan dan pangkat/golongan dapat disajikan seperti pada tabel 4.2 berikut : 
Dari tabel 4.2 diatas, terlihat bahwa karakteristik responden dengan umur diatas 50 tahun $(39,1 \%)$ dan $46-50$ thun $(39,1 \%)$, jenis kelamin laki-laki $(62,5 \%)$, status perkawinan, kawin (75\%), masa kerja diatas 25 tahun $(37,5 \%)$, tingkat pendidikan SLTA $(50,0 \%)$ dan pangkat/golongan terbesar III/a, II/d serta II/b (25,0\%), menunjukkan bahwa mayoritas tenaga kependidikan (karyawan) telah mempunyai masa kerja yang lama dan pangkat/golongan yang telah berada pada tingkat yang sesuai dengan masa kerja.

\section{Uji Validitas dan Reliabilitas}

Pembahasan yang dilakukan dalam penelitin ini adalah statistik deskripsi, yaitu menggunakan metode perhitungan mean dan prosentase. Sebelum melakukan analisis dari hipotesis penelitian, maka kuesioner yang dibagikan kepada responden atau sampel akan diuji dengan menggunakan uji validitas dan reliabilitas. Hal ini sebagai syarat untuk dapat menggunakan dan dimaksudkan agar perangkat penelitian yang digunakan dapat mengukur dan mampu mengungkapkan data secara tepat.

Validitas adalah ketepatan atau kecermatan suatu instrumen dalam

pengukuran. Dalam pengujian instrumen pengumpulan data, validitas dibedakan menjadi validitas faktor dan validitas item. Validitas faktor diukur bila item yang disusun menggunakan lebih dari satu faktor yaitu dengan cara mengkorelasikan antara skor faktor dengan skor total item, sedangkan pengukuran validitas item dengan cara mengkorelasikan antara skor item dengan skor total item.

\section{Uji Validitas}

Pengujian validitas data dalam penelitian ini menggunakan metode korelasi Bivariate Pearson (Korelasi Pearson Product Moment) Analisis ini dilakukan dengan cara mengkorelasi masingmasing skor item dengan total skor. Total skor adalah penjumlahan dari keseluruhan item. Item-item pertanyaan yang berkorelasi signifikan dengan skor total menunjukkan itemitem tersebut mampu memberikan dukungan dalam mengungkap apa yang diungkap. Instrumen dinyatakan valid apabila hasil korelasi hitungnya berada di atas 0,30 (Sugiyono, 2009). Tabel berikut menunjukan hasil uji validitas :

TABEL 4.3

Hasil Uji Validitas Kinerja Dosen

\begin{tabular}{ccccc}
\hline Indikator & Item & $\mathrm{r}_{\text {hitung }}$ & $\mathrm{r}_{\text {tabel }}$ & Keterangan \\
\hline X1 & 0,834 & 0,413 & Valid \\
X2 & 0,703 & 0,413 & Valid \\
X3 & 0,635 & 0,413 & Valid \\
X4 & 0,525 & 0,413 & Valid \\
X5 & 0,540 & 0,413 & Valid \\
Kinerja Dosen & X6 & 0,633 & 0,413 & Valid \\
& X7 & 0,834 & 0,413 & Valid \\
& X8 & 0,703 & 0,413 & Valid \\
X9 & 0,635 & 0,413 & Valid \\
& X10 & 0,708 & 0,413 & Valid \\
& X11 & 0,743 & 0,413 & Valid \\
X12 & 0,815 & 0,413 & Valid \\
& X13 & 0,576 & 0,413 & Valid \\
& X14 & 0,625 & 0,413 & Valid \\
& X15 & 0,582 & 0,413 & Valid \\
\hline
\end{tabular}

Sumber : Data primer diolah kembali, 2017 
Berdasarkan tabel 4.3, menunjukkan bahwa pengujian data kinerja dosen, semua item pernyataan / pertanyaan dinyatakan valid, karena rhitung > rtabel $(0,413)$, dengan jumlah $\mathrm{n}=23$ dan taraf signifikan $=5 \%$ pada table $\mathrm{r}$ (Product Moment) ditunjukkan oleh angka 0,413.

Adapun uji validtas kinerja karyawan seperti tampak pada tabel 4.4 berikut :

TABEL 4.4

Hasil Uji Validitas

Kinerja Karyawan

\begin{tabular}{ccccc}
\hline Indikator & Item & r hitung & r tabel & Keterangan \\
& X1 & 0,765 & 0,707 & Valid \\
& X2 & 0,941 & 0,707 & Valid \\
& X3 & 0,752 & 0,707 & Valid \\
Kinerja Karyawan & X4 & 0,731 & 0,707 & Valid \\
& X5 & 0,842 & 0,707 & Valid \\
& X6 & 0,735 & 0,707 & Valid \\
& X7 & 0,802 & 0,707 & Valid \\
X8 & 0,865 & 0,707 & Valid \\
& X9 & 0,765 & 0,707 & Valid \\
& X10 & 0,947 & 0,707 & Valid \\
\hline
\end{tabular}

Sumber : Data primer diolah kembali, 2017

Dari hasil di atas menunjukkan bahwa pengujian data kinerja karyawan semua item pernyataan / pertanyaan dinyatakan valid, karena rhitung > rtabel $(0,707)$, dengan jumlah $\mathrm{n}=8$ dan taraf signifikan $=5 \%$ pada table $\mathrm{r}$ (Product Moment) ditunjukkan oleh angka 0,707 .

\section{Uji Reliabilitas}

Teknik yang digunakan untuk mengukur tingkat reliabilitas adalah Cronbach's Alpha dengan cara membandingkan nilai Alpha dengan standarnya, yaitu jika memiliki Cronbach's Alpha > 0,6 maka suatu instrument dapat diterima dan dikatakan reliabel (Sugiyono, 2009;78).

Tabel berikut menunjukkan hasil pengujian reliabilitas dengan menggunakan program SPSS.

TABEL 4.5

Hasil Uji Reliabilitas

\begin{tabular}{ccc}
\hline Indikator & Nilai $\alpha$ & Keterangan \\
\hline Kinerja Dosen & 0,895 & Reliabel \\
Kinerja Karyawan & 0,690 & Reliabel \\
\hline
\end{tabular}

Sumber : Data primer diolah kembali, 2017

Berdasar Tabel 4.5 di atas dapat dilihat bahwa setelah dilakukan pengujian semua variabel memiliki nilai Cronbach Alpha $>0,6$ oleh karenanya dapat disimpulkan bahwa instrument dapat diterima dan dikatakan reliabel.

\section{Deskripsi Indikator Kinerja tenaga Pendidik (dosen)}

Untuk menggambarkan indikator kinerja tenaga pendidik (dosen) distribusi tanggapan responden terhadap keseluruhan item pertanyaan seperti tampak pada tabel 4.6 berikut : 
TABEL 4.6

Kinerja Dosen

Distribusi Tanggapan Responden Dosen pada Masing-Masing Indikator

\begin{tabular}{|c|c|c|c|}
\hline Indikator & No & Item & Mean \\
\hline \multirow[t]{5}{*}{ A. Pembelajaran } & $\mathrm{X} 1$ & $\begin{array}{l}\text { Pada awal perkuliahan Bapak/Ibu/Sdr } \\
\text { menyampaikan tentang kemampuan yang } \\
\text { didapatkan mahasiswa setelah mengikuti } \\
\text { perkuliahan ini. }\end{array}$ & 4,26 \\
\hline & $\mathrm{X} 2$ & $\begin{array}{l}\text { Apakah Bapak/Ibu/Sdr selalu menjelaskan } \\
\text { dengan baik tentang pokok-pokok } \\
\text { perkuliahan dan metode pembelajaran }\end{array}$ & 4,17 \\
\hline & $\mathrm{X} 3$ & $\begin{array}{l}\text { Apakah Bapak/Ibu/Sdr selalu menjelaskan } \\
\text { dengan baik tentang sistem penilaian yang } \\
\text { diberikan kepada mahasiswa serta } \\
\text { mengembalikan } \\
\text { mahasiswa }\end{array}$ & 3,22 \\
\hline & $\mathrm{X} 4$ & $\begin{array}{l}\text { Apakah Bapak/Ibu/Sdr sealu menyediakan } \\
\text { dengan baik buku ajar, buku kerja atau } \\
\text { handouts yang berkaitan dengan mata } \\
\text { kuliah yang diampu }\end{array}$ & 4,26 \\
\hline & $\mathrm{X} 5$ & $\begin{array}{l}\text { Menurut Bapak/Ibu/Sdr apakah memberi } \\
\text { tugas secara kelompok } \\
\text { menumbuhkan inspirasi dan motivasi } \\
\text { mahasiswa dalam belajar }\end{array}$ & 3,13 \\
\hline \multirow[t]{5}{*}{ B. Keterampilan } & X6 & $\begin{array}{l}\text { Apakah Bapak/Ibu/Sdr selalu memberi } \\
\text { materi perkuliahan yang mengakibatkan } \\
\text { mahasiswa berpikir kritis dan rasional }\end{array}$ & 4,22 \\
\hline & $\mathrm{X} 7$ & $\begin{array}{l}\text { Apakah Bapak/Ibu/Sdr selalu menjelaskan } \\
\text { dan mempresentasikan ide-ide dengan cara } \\
\text { yang jelas dari materi kuliah yang } \\
\text { diajarkan }\end{array}$ & 4,17 \\
\hline & $\mathrm{X} 8$ & $\begin{array}{l}\text { Apakah Bapak/Ibu/Sdr selalu menjelaskan } \\
\text { dan mengembangkan komunikasi sebagai } \\
\text { akibat dari aktivitas mata kuliah yang } \\
\text { diajarkan }\end{array}$ & 4,35 \\
\hline & $\mathrm{X} 9$ & Apakah $\quad$ Bapak/Ibu/Sdr selalu & \\
\hline & & $\begin{array}{l}\text { mengarahkan tugas kelompok atau tim dari } \\
\text { pada tugas individu dari mata kuliah yang } \\
\text { diampu }\end{array}$ & 3,87 \\
\hline \multirow[t]{2}{*}{$\begin{array}{l}\text { C. Penilaian dan } \\
\text { beban kerja }\end{array}$} & $\mathrm{X} 10$ & $\begin{array}{l}\text { Apakah Bapak/Ibu/Sdr selalu memberikan } \\
\text { penilaian dengan objektif kepada } \\
\text { mahasiswa sesuai dengan kemampuan dan } \\
\text { daya tangkap mahasiswa atas materi mata } \\
\text { kuliah yang diajarkan }\end{array}$ & 4,04 \\
\hline & $\mathrm{X} 11$ & $\begin{array}{l}\text { Apakah Bapak/Ibu/Sdr selalu } \\
\text { memperhitungkan pekerjaan kelompok } \\
\text { dari pada pekerjaan individu untuk } \\
\text { mengevaluasi hasil dari mata kuliah yang } \\
\text { diajarkan }\end{array}$ & 3,87 \\
\hline
\end{tabular}



D. Bimbingan X12 Apakah Bapak/Ibu/Sdr selalu memberikan dan
Konseling
bimbingan belajar terhadap mahasiswa
yang Bapak/Ibu/Sdr ampu

E. Sumber

Pembelajaran

X13 Apakah Bapak/Ibu/Sdr selalu menjelaskan dengan baik tentang pilihan mata kuliah mana yang dibutuhkan oleh mahasiswa dimana Bapak/Ibu/Sdr merupakan penasehat akademik mahasiswa yang bersangkutan

X14 Apakah Bapak/Ibu selalu menggunakan fasilitas sound system, LCD proyektor saat

3,96 memberikan atau mengajar mata kuliah yang dibina

X15 Apakah Bapak/Ibu/Sdr selalu menganjurkan kepada mahasiswa untuk menggunakan fasilitas perpustakaan 4,26 sebagai sarana mendapatkan buku atau literatur-literatur yang berkaitan dengan mata kuliah yang disajikan oleh Perguruan Tinggi

Total Mean

Total Mean rata-rata Kinerja Dosen

Sumber : Data primer diolah kembali, 2017

\section{Frekuensi Indikator Kinerja Dosen}

Adapun prekuensi indikator kinerja dosen disajikan seperti pada tabel 4.7 berikut :

TABEL 4.7

FREKUENSI INDIKATOR KINERJA DOSEN

\begin{tabular}{|c|c|c|c|c|c|c|c|c|c|c|c|c|c|c|}
\hline \multicolumn{15}{|c|}{ SKOR } \\
\hline \multirow{2}{*}{ INDIKATOR } & \multicolumn{2}{|c|}{1} & \multicolumn{2}{|c|}{2} & \multicolumn{2}{|c|}{3} & \multicolumn{2}{|c|}{4} & \multicolumn{2}{|c|}{5} & \multicolumn{2}{|c|}{ TOTAL } & \multicolumn{2}{|c|}{ TOTAL SKOR } \\
\hline & $\mathrm{F}$ & $\%$ & $\mathrm{~F}$ & $\%$ & $\mathrm{~F}$ & $\%$ & $\mathrm{~F}$ & $\%$ & $\mathrm{~F}$ & $\%$ & $\mathrm{~F}$ & $\%$ & TS & RTS \\
\hline $\mathrm{X} 1$ & 0 & 0 & 0 & 0 & 2 & 8,7 & 13 & 56,5 & 8 & 34,8 & 23 & 100 & 98 & 4,26 \\
\hline $\mathrm{X} 2$ & 0 & 0 & 0 & 0 & 2 & 8,7 & 15 & 66,2 & 6 & 26,1 & 23 & 100 & 96 & 4,17 \\
\hline $\mathrm{X} 3$ & 0 & 0 & 5 & 21,7 & 10 & 43,5 & 6 & 26,1 & 2 & 8,7 & 23 & 100 & 74 & 3,22 \\
\hline $\mathrm{X} 4$ & 0 & 0 & 0 & 0 & 2 & 8,7 & 13 & 56,5 & 8 & 34,8 & 23 & 100 & 98 & 4,26 \\
\hline $\mathrm{X} 5$ & 2 & 8,7 & 5 & 21,7 & 7 & 30,4 & 6 & 26,1 & 3 & 13,0 & 23 & 100 & 72 & 3,13 \\
\hline X6 & 0 & 0 & 0 & 0 & 3 & 13,0 & 12 & 52,2 & 8 & 34,8 & 23 & 100 & 97 & 4,22 \\
\hline $\mathrm{X} 7$ & 0 & 0 & 0 & 0 & 3 & 13,0 & 13 & 56,5 & 7 & 30,4 & 23 & 100 & 96 & 4,17 \\
\hline X8 & 0 & 0 & 0 & 0 & 2 & 8,7 & 11 & 47,8 & 10 & 43,5 & 23 & 100 & 100 & 4,35 \\
\hline X9 & 0 & 0 & 0 & 0 & 7 & 30,4 & 12 & 52,2 & 4 & 17,4 & 23 & 100 & 89 & 3,87 \\
\hline X10 & 0 & 0 & 0 & 0 & 5 & 21,7 & 12 & 52,2 & 6 & 26,1 & 23 & 100 & 93 & 4,04 \\
\hline X11 & 0 & 0 & 0 & 0 & 8 & 34,8 & 10 & 43,5 & 5 & 21,7 & 23 & 100 & 89 & 3,87 \\
\hline $\mathrm{X} 12$ & 0 & 0 & 0 & 0 & 6 & 26,1 & 12 & 52,2 & 5 & 21,7 & 23 & 100 & 91 & 3,96 \\
\hline X13 & 0 & 0 & 0 & 0 & 3 & 13,0 & 11 & 47,8 & 9 & 39,1 & 23 & 100 & 98 & 4,26 \\
\hline X14 & 0 & 0 & 0 & 0 & 4 & 17,4 & 13 & 56,5 & 6 & 26,1 & 23 & 100 & 94 & 4,09 \\
\hline X15 & 0 & 0 & 0 & 0 & 3 & 13,0 & 14 & 60,9 & 6 & 26,1 & 23 & 100 & 95 & 4,13 \\
\hline
\end{tabular}

Sumber : Data primer diolah kembali, 2017 


\section{Deskripsi Indikator Kinerja tenaga Kependidikan (karyawan)}

Untuk menggambarkan indikator kinerja tenaga kependidikan (karyawan) distribusi tanggapan responden terhadap keseluruhan item pertanyaan seperti tampak pada tabel 4.8 berikut :

TABEL 4.8

Distribusi Tanggapan Responden Karyawan pada Masing-Masing Indikator Kinerja Karyawan

\begin{tabular}{|c|c|c|c|}
\hline Indikator & No & Item & Mean \\
\hline \multirow[t]{3}{*}{$\begin{array}{l}\text { A. Tanggung } \\
\text { Jawab }\end{array}$} & $\mathrm{X} 1$ & $\begin{array}{l}\text { Apakah Bapak/Ibu/Sdr selalu mengerjakan } \\
\text { tugas sesuai aturan yang ditetapkan }\end{array}$ & 3,88 \\
\hline & $\mathrm{X} 2$ & $\begin{array}{l}\text { Apakah Bapak/Ibu/Sdr selalu mengerjakan } \\
\text { pekerjaan dengan sungguh-sungguh }\end{array}$ & 3,75 \\
\hline & $\mathrm{X} 3$ & $\begin{array}{l}\text { Apakah Bapak/bu/Sdr selalu mengevaluasi } \\
\text { atas hasil atau tugas yang dipercayakan } \\
\text { selama ini }\end{array}$ & $3, \mathbf{8 8}$ \\
\hline \multirow[t]{3}{*}{ B. Kualitas } & $\mathrm{X} 4$ & $\begin{array}{l}\text { Apakah Bapak/Ibu/Sdr selalu merasa hasil } \\
\text { kerja semakin baik karena adanya } \\
\text { kerjasama tim yang disarankan oleh pihak } \\
\text { yayasan }\end{array}$ & 3,63 \\
\hline & $\mathrm{X} 5$ & $\begin{array}{l}\text { Menurut Bapak/Ibu/Sdr apakah pelatihan } \\
\text { yang diterima selama ini berpengaruh } \\
\text { terhadap kualitas kerja }\end{array}$ & 3,75 \\
\hline & X6 & 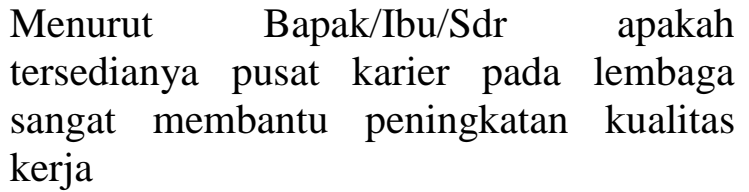 & 2,63 \\
\hline \multirow[t]{2}{*}{ C. Kuantitas } & $\mathrm{X} 7$ & $\begin{array}{l}\text { Apakah Bapak/Ibu/Sdr selalu mencapai } \\
\text { target atas pekerjaan yang ditugaskan } \\
\text { selama ini }\end{array}$ & 3,63 \\
\hline & $\mathrm{X} 8$ & $\begin{array}{l}\text { Apakah Bapak/Ibu/Sdr selalu berusaha } \\
\text { untuk mendapatkan jumlah mahasiswa } \\
\text { baru yang masuk dengan segala daya dan } \\
\text { upaya yang Bapak/Ibu/Sdr miliki }\end{array}$ & 3,13 \\
\hline \multirow[t]{4}{*}{ D. Disiplin } & X9 & $\begin{array}{l}\text { Apakah Bapak/Ibu/Sdr selalu hadir tepat } \\
\text { waktu sesuai dengan jam kerja }\end{array}$ & 3,25 \\
\hline & $\mathrm{X} 10$ & $\begin{array}{l}\text { Apakah Bapak/Ibu/Sdr selalu bekerja } \\
\text { dengan memperhatikan jam kerja serta jam } \\
\text { pulang kerja sesuai dengan peraturan yang } \\
\text { ada pada lembaga }\end{array}$ & 3,13 \\
\hline & & Total mean & 34,63 \\
\hline & & Total Mean rata-rata Kinerja Karyawan & 3,46 \\
\hline
\end{tabular}

Sumber : Data primer diolah kembali, 2017

Berdasarkan Tabel 4.7 dan 4.8 di atas, menunjukkan indikator kinerja dosen, mean terbesar ditunjukkan oleh item pertanyaan Apakah Bapak/Ibu/Sdr selalu menjelaskan dan mengembangkan komunikasi sebagai akibat dari aktivitas mata kuliah yang diajarkan (4,35), mean terkecil dapat dilihat pada item pertanyaan menurut Bapak/Ibu/Sdr apakah memberi tugas secara kelompok dapat menumbuhkan inspirasi dan motivasi mahasiswa dalam belajar. Sedangkan mean terbesar untuk kinerja 
karyawan dengan item pertanyaan Apakah Bapak/Ibu/Sdr selalu mengevaluasi atas hasil atau tugas yang dipercayakan selama ini $(3,88)$, dan mean terkecil pada pertanyaan Apakah Bapak/Ibu/Sdr selalu memberi materi perkuliahan yang mengakibatkan mahasiswa berpikir kritis dan rasional $(2,63)$.

6. Frekuensi Indikator Kinerja Karyawan

TABEL 4.9

FREKUENSI INDIKATOR KINERJA KARYAWAN

\begin{tabular}{|c|c|c|c|c|c|c|c|c|c|c|c|c|c|c|}
\hline \multicolumn{15}{|c|}{ SKOR } \\
\hline \multirow[t]{2}{*}{ INDIKATOR } & \multicolumn{2}{|c|}{1} & \multicolumn{2}{|c|}{2} & \multicolumn{2}{|c|}{3} & \multicolumn{2}{|c|}{4} & \multicolumn{2}{|c|}{5} & \multicolumn{2}{|c|}{ TOTAL } & \multicolumn{2}{|c|}{$\begin{array}{c}\text { TOTAL } \\
\text { SKOR }\end{array}$} \\
\hline & $\mathrm{F}$ & $\%$ & $\mathrm{~F}$ & $\%$ & $\mathrm{~F}$ & $\%$ & $\mathrm{~F}$ & $\%$ & $\mathrm{~F}$ & $\%$ & $\mathrm{~F}$ & $\%$ & & \\
\hline $\mathrm{X} 1$ & 0 & 0 & 0 & 0 & 3 & 37,5 & 3 & 37,5 & 2 & 25,0 & 8 & 100 & 31 & 3,88 \\
\hline $\mathrm{X} 2$ & 0 & 0 & 0 & 0 & 3 & 37,5 & 4 & 50,0 & 1 & 12,5 & 8 & 100 & 30 & 3,75 \\
\hline X3 & 0 & 0 & 0 & 0 & 3 & 37,5 & 3 & 37,5 & 2 & 25,0 & 8 & 100 & 31 & 3,88 \\
\hline $\mathrm{X} 4$ & 0 & 0 & 0 & 0 & 4 & 50,0 & 3 & 37,5 & 1 & 12,5 & 8 & 100 & 29 & 3,63 \\
\hline $\mathrm{X} 5$ & 0 & 0 & 0 & 0 & 3 & 37,5 & 4 & 50,0 & 1 & 12,5 & 8 & 100 & 30 & 3,75 \\
\hline X6 & 0 & 0 & 0 & 0 & 4 & 50,0 & 3 & 37,5 & 1 & 12,5 & 8 & 100 & 21 & 2,63 \\
\hline $\mathrm{X} 7$ & 0 & 0 & 0 & 0 & 4 & 50,0 & 3 & 37,5 & 1 & 12,5 & 8 & 100 & 29 & 3,63 \\
\hline X8 & 0 & 0 & 2 & 25,0 & 4 & 50,0 & 1 & 12,5 & 1 & 12,5 & 8 & 100 & 25 & 3,13 \\
\hline X9 & 0 & 0 & 0 & 0 & 6 & 75,0 & 2 & 25,0 & 0 & 0 & 8 & 100 & 26 & 3,25 \\
\hline $\mathrm{X} 10$ & 0 & 0 & 1 & 12,5 & 5 & 62,5 & 2 & 25,0 & 0 & 0 & 8 & 100 & 25 & 3,13 \\
\hline
\end{tabular}

Sumber : Data primer diolah kembali, 2017

\section{A. Kesimpulan}

1. Penilaian kinerja adalah proses yang dilakukan organisasi untuk mengevaluasi hasil kerja para karyawannya. Penilaian kinerja adalah sistem formal untuk meninjau dan mengevaluasi kinerja para individu atau tim dalam menjalankan tugasnya.

2. Penilaian kinerja melibatkan evaluasi kinerja yang didasarkan pada penilaian dan pendapat dari para bawahan, rekan kerja, atasan, manajer lainnya, dan bahkan karyawan itu sendiri. Penilaian kinerja adalah proses formal untuk mengevaluasi kinerja dan memberi umpan balik.

3. Kinerja tenaga pendidik (dosen) pada STIMI Banjarmasin sudah baik yang ditunjukkan oleh mean rata-rata dari indikator kinerja dosen menunjukkan angka 4,00, sedangkan kinerja tenaga kependidikan (karyawan) hanya cukup baik yang ditunjukkan oleh mean rata-rata indikatornya hanya sebesar 3,46.

\section{B. Saran}

1. Penelitian berikutnya hendaknya dapat mengangkat judul penelitian : Analisis faktor-faktor yang mempengaruhi kinerja dosen maupun karyawan.

2. Hendaknya ditambahkan indikator lain selain indikator yang digunakan untuk mengukur Kinerja dosen maupun karyawan seperti yang disarankan pada beberapa literatur.

Untuk mengukur kinerja dosen dapat dilakukan melalui kualitas hasil kerja, kemampuan, prakarsa, komunikasi dan ketapatan waktu. Sedangkan untuk mengukur kinerja karyawan dapat dilakukan melalui kuantitas output, kualitas output, jangka waktu output, kehadiran ditempat kerja serta sikap kooperatif melalui kuesioner yang berkaitan dengan variabel yang diteliti. 


\section{DAFTAR PUSTAKA}

Arikunto, Suharsimi, 2006, Prosedur Penelitian Suatu Pendekatan Praktik, Rineka Cipta, Jakarta.

Dessler, G., 2006, Manajemen Sumber Daya Manusia, PT. Indeks, Jakarta.

Fathoni, Abdurrahmat, 2006, Organisasi dan Manajemen Sumber Daya Manusia, Rineka Cipta, Bandung.

Goleman Daniel, 2015, Kecerdasan Emosional, PT. Gramedia, Jakarta.

Gomes, Cardoso Faustino, 1995, Manajemen Sumber Daya Manusia, Andi Offset, Yogyakarta.

Handoko, T. Hani, 1996, Manajemen Personalia dan Sumber Daya Manusia, BPFE, Yogyakarta.

Hasibuan, S.P. Malayu, 2003, Manajemen sumber Daya Manusia, PT. Bumi Aksara, Jakarta.

Husnan Suad, Heidjrachman, 2002, Manajemen Personalia, BPFE, Yogyakarta.

Mangkunegara, Anwar Prabu, 2007, Manajemen Sumber Daya Manusia Perusahaan, PT. Remaja Rosdakarya, Bandung.

Manullang, 2004, Manajemen Personalia, Cetakan Kedua, UGM Press, Yogyakarta.
Martoyo, Susilo, 2000, Manajemen Sumber Daya Manusia, BPFE, Yogyakarta.

Mondy, R.W., 2008, Manajemen Sumber Daya Manusia, Erlangga, Jakarta.

Schermerhorn, J.R., 1996, Management, $5^{\text {th }}$ Ed., New York: John Wiley \& Sons, Inc.

Schuler, R.S. \& Jackson, S.E., 2006, Human Resource Management, International Perspective, Mason: Thomson South-Western.

Sedarmayanti, 2009, Manajemen Sumber Daya Manusia, Reformasi Birokrasi dan Manajemen Pegawai Negeri Sipil, PT. Refika Aditama, Bandung.

Siagian P Sondang, 2003, Manajemen Sumber Daya Manusia, Bumi Aksara, Jakarta.

Sulistyo, Joko,2010, 6 Hari Jago SPSS 17, Cakrawala, Yogyakarta.

Triton, PB, 2005, Paradigma Baru Manajemen Sumber Daya Manusia, Tugu Publisher, Yogyakarta.

Wibowo, 2007, Manajemen Kinerja, PT.

Rajagrafindo Persada, Jakarta.

Werther, W.B. \& Davis, K., 1996, Human Resources and Personnel Management, $5^{\text {th }}$ Ed., Boston: McGraw-Hill. 